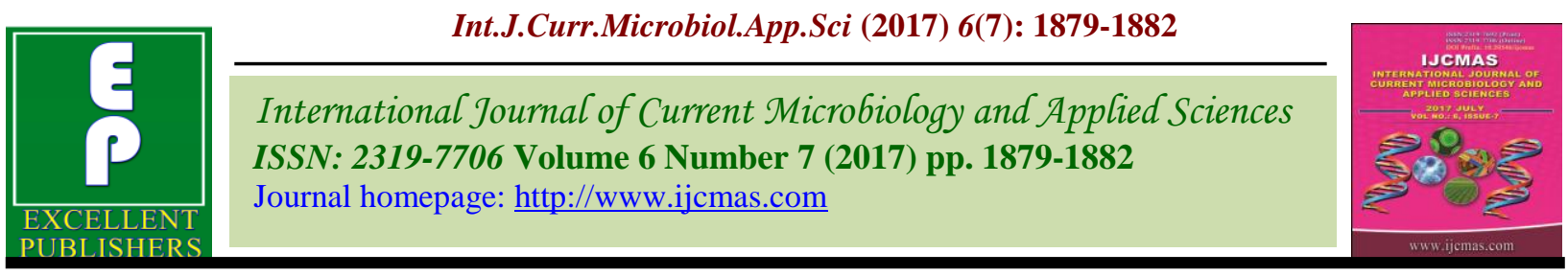

Original Research Article

https://doi.org/10.20546/ijcmas.2017.607.224

\title{
Role of Honeybee (Apis mellifera) in Enhancing Yield of Mustard in Humid Region of Rajasthan, India
}

\author{
B.K. Patidar*, K.N. Ojha and I.U. Khan \\ All India Coordinated Research Project on Honey Bee and Pollinator, Agricultural Research \\ Station, Ummedganj, Kota, Rajasthan 324001, India \\ *Corresponding author
}

\section{A B S T R A C T}

\begin{tabular}{|c|c|}
\hline & Mustard (Brassica spp.), family cruciferae are the major oilseed crop grow throughout \\
\hline $\begin{array}{l}\text { Ke y w o r d s } \\
\text { Honeybee, } \\
\text { Mustard, } \\
\text { Pollination } \\
\text { treatments, } \\
\text { Pollinators }\end{array}$ & $\begin{array}{l}\text { India for edible oil. It is an open pollinated crop and honeybees are effective pollinators for } \\
\text { open pollinated crops because of a lot of nectar and pollens are available on the flowers of } \\
\text { mustard. The studies were conducted during rabi 2013-14 and 2014-15 at ARS, Kota to } \\
\text { enhance the yield of mustard through honey bee pollinator. Mustard variety "Bio-902" was } \\
\text { grown following all recommended agronomic practices without spraying through the crop } \\
\text { season. The colonies of honeybee (Apis mellifera) were placed in cage measuring } 10 X 10 \\
\text { sq. meters before the initiation of flowering. The present study contained three pollination }\end{array}$ \\
\hline Article Info & $\begin{array}{l}\text { treatments viz., Plants caged Pollinator Exclusion (PE), Plants caged with bee hive (BP) } \\
\text { and Plants kept open to all pollinators (OP). The comparative data pertaining to modes of }\end{array}$ \\
\hline $\begin{array}{l}\text { Accepted: } \\
\text { 21 June } 2017 \\
\text { Available Online: } \\
\text { 10 July } 2017\end{array}$ & $\begin{array}{l}\text { pollination in mustard crop revealed that highest values of mean no. of siliqua/plant } \\
\text { (186.44), no. of seeds/ siliqua }(13.82) \text { and seed yield }(20.54 \mathrm{q} / \mathrm{ha}) \text { were obtained from OP } \\
\text { followed by BP and it was recorded lowest in PE. The introduction of honeybees in } \\
\text { agricultural crops plays a vital role in pollination which in turn resulted in higher } \\
\text { production of seed vield as well as honey production. }\end{array}$ \\
\hline
\end{tabular}

\section{Introduction}

Mustard (Brassica spp.), is an important oil seed crop, cultivated for edible oil throughout the country with average productivity of 1234 $\mathrm{kg} / \mathrm{ha}$ in 2012-13 (Anonymous, 2014). Cross pollination of entomophilous crops by honeybees is considered as one of the effective and cheapest method for triggering the crop yield both qualitatively and quantitatively. Being the pollination service provider bees contribute handsomely in enhancing the productivity and production of cross pollinated crops through efficient pollination in an inconspicuous and silent manner (Singh et al., 2005 and Mohapatra et al., 2010). Honeybees (Apis mellifera) are the only pollinators which can be hived in beeboxes and moved from place to place, installed in the field for pollination as and when required. Therefore, numbers of studies are being carried out to find effective and efficient ways of bee pollination in Brassica as well as other crops throughout the world.

The present study is directed towards to assess the role of honeybees, in enhancing the yield of mustard in an inconspicuous and silent manner in increase number of siliqua per plant and number of seeds per siliqua. 


\section{Materials and Methods}

Field investigations were carried out during rabi 2013-14 and 2014-15 at the Agricultural Research Station, Ummedganj, Kota. The mustard variety "Bio 902" was sowing during the month of mid-September to first week of October in gross plot of 10x10 Sq. feet following all the recommended agronomic practices.

The plots were kept unsprayed throughout the crop season. There were three treatments, viz., Plants caged Pollinator exclusion (PE), Plants caged with bee hive (BP) and Plants kept open to all pollinators (OP). In treatment of bee pollination, a bee colony with Apis mellifera box was used and kept till completion of flowering.

For this purpose special bee hive boxes with back and front entrance was kept open in one boundary of cage to facilitate the bees to move in and out of the cage. The fine nylon mosquito net cages of size $10 \times 10 \times 12$ feet were erected on standing crop before the initiation of flowering.

Iron pipe are used for making the cage to hold the nylon net in position. Lower edges of the mosquito net were touched to the ground so as to exclude hovering insects away from the covered plants.

Each treatment was replicated eight times in a randomized block design. The observations viz., no. of siliqua per plant, no. of seeds/ siliqua and seed yield was recorded for each plot under each treatment.

\section{Results and Discussion}

There were significant differences for all the quantitative parameters investigated among the different pollination methods.
In mean data highest values were obtained from open pollination, followed by plants caged with $A$. mellifera hives and plants caged without access to any pollinators (PE).

The mean data of no. of siliqua per plant (Table 1) showed maximum 186.44 in plots having free access to all the pollinators (OP) followed by 154.82 in BP.

The lowest i.e. 133.38 number of siliqua/ plant were recorded in PE. Ahmed and Rehman (2002) observed in mustard that the number of siliquae per plant was significantly higher in OP (189.60-190.24) over PWI (120.93-120.69).

Thapa (2006) found in Indian mustard about 11 per cent increased in pod setting.

The mean data in terms of no. of seed/siliqua as shown in table 1 of the two years revealed that maximum 13.82 in OP followed by 12.75 with BP. The lowest i.e. 11.19 was recorded in PE.

Many researchers reported similar results, Verma and Joshi (1983) reported that on mustard bloom, honeybee pollination increased the number of seeds by 4.07 per pod.

Delbrassinne and Rasmont (1988) reported that intensive pollination of Brassica juncea linn. By A. mellifera increased the number of seeds per pod (12.22\%), Panda et.al. (1989) obtained average seed number / pod was 10.80 whereas without insects were 5.90. Ahmed and Rehman (2002) found that the number of seeds per siliqua (12.04-12.60) per cent higher than PWI in the two varieties of rape seed.

Sanas et al., (2014) also found that $A$. mellifera increased the number of seed per pod $(23.27 \%)$ in mustard under Konkan condition of Maharastra. 
Table.1 The yield attributing parameters as affected by Different modes of pollination treatments in mustard

\begin{tabular}{lcccccc}
\hline Modes of Pollination & \multicolumn{5}{c}{ Yield attributing characters } \\
\cline { 2 - 7 } & \multicolumn{3}{c}{ No. of siliqua/plant } & \multicolumn{3}{c}{ No. of seed/Siliqua } \\
\cline { 2 - 7 } & $\mathbf{2 0 1 3 - 1 4}$ & $\mathbf{2 0 1 4 - 1 5}$ & Mean & $\mathbf{2 0 1 3 - 1 4}$ & $\mathbf{2 0 1 4 - 1 5}$ & Mean \\
\hline Pollinator exclusion (PE) & 132.63 & 134.13 & 133.38 & 10.75 & 11.63 & 11.19 \\
Bee pollination (BP) & 155.75 & 153.88 & 154.82 & 13.25 & 12.25 & 12.75 \\
Open pollination (OP) & 188.13 & 184.75 & 186.44 & 14.50 & 13.13 & 13.82 \\
S.Em ( \pm ) & 1.561 & 2.308 & - & 0.562 & 0.331 & - \\
C.D. $(5 \%)$ & 4.704 & 7.001 & - & 1.693 & 1.003 & - \\
\hline
\end{tabular}

* All observations are mean of eight replications.

Table.2 Role of honeybees in enhancing yield of mustard crop in different modes of pollination

\begin{tabular}{lcccc}
\hline Modes of pollination & \multicolumn{4}{c}{ Yield (kg/ha) } \\
\cline { 2 - 5 } & $\mathbf{2 0 1 3 - 1 4}$ & $\mathbf{2 0 1 4 - 1 5}$ & Mean & $\begin{array}{l}\text { \% increase/decrease } \\
\text { Over PE }\end{array}$ \\
\cline { 2 - 5 } Pollinator exclusion (PE) & 1509.38 & 1577.00 & 1543.19 & - \\
Bee pollination (BP) & 1785.00 & 1875.00 & 1830.00 & $(+) 15.30$ \\
Open pollination (OP) & 2040.00 & 2068.75 & 2054.38 & $(+) 26.99$ \\
S.Em $( \pm)$ & 72.795 & 70.659 & - & - \\
C.D. $(5 \%)$ & 220.798 & 214.319 & - & - \\
\hline
\end{tabular}

*All observations are mean of eight replications.

Similarly mean data of seed yield $(\mathrm{kg} / \mathrm{ha})$ table 2 showed maximum $2054.38 \mathrm{~kg} / \mathrm{ha}$ in OP followed by $1830.00 \mathrm{~kg} / \mathrm{ha}$ in BP. The lowest seed yield $15.43 .19 \mathrm{~kg} / \mathrm{ha}$ found with PE. The data of OP and BP showed about 26.99 and 15.30 percent increased seed yield over PE, respectively.

There are many studies showing the pollinator's role and findings are confirmative with Prasad et.al. (1989) they reported in $B$. juncea, open pollination gave the maximum yield $(13.4 \mathrm{q} / \mathrm{ha})$ followed by plots caged with one $A$. cerana honeybee colony (11.3 q/ha), whereas plots caged without bees (exclusion of pollinators) gave the lowest seed yield (10 q/ha). Chand and Singh (1995), reported that the mustard plots caged without any pollinator had lowest seed yield $(966 \mathrm{~kg} / \mathrm{ha})$. Whereas, the free access to all the pollinator showed the maximum yield $(1620 \mathrm{~kg} / \mathrm{ha})$ followed by plots caged with honeybees (1160 kg/ha). Sanas et al., (2014), also reported that mustard plot gave maximum seed yield $(963.45 \mathrm{Kg} / \mathrm{ha})$ pollinated by free access to all pollinators and lowest yield $(602.52 \mathrm{Kg} / \mathrm{ha})$ in pollination without insect. Whereas plots gave yield $(763.75 \mathrm{Kg} / \mathrm{ha})$ pollinated by honeybees (A. cerana indica $\mathrm{Fab})$.

\section{Acknowledgement}

The authors are thankful to the Zonal Director Research, Agricultural Research Station, Agriculture University, Kota for providing necessary facilities.

\section{References}

Anonymous, 2014. Agricultural Statistics- At a Glance, Govt. of India Ministry of 
Agriculture, Department of Agriculture and Cooperation, Directorate of Economics \& Statistics. Pp-111.

Ahmed, B. and Rehman, A. 2002. Population dynamics of insect foragers and their effect on yield of rapeseed (Brassica campestris L. var. toria). Indian Bee Journal. 64 (3\&4): 1-5.

Chand, H. and Singh, B. 1995. Effect of pollination by Apis cerana $\mathrm{F}$. on yield of mustard, Brassica juncea L. Indian Bee Journal. 57 (1): 173-174.

Delbrassinne, S. and Rasmont, P. 1988. Cotribution to the study of pollination of rape, Brassica napus var. oleiera in Belgium. Bull des Recherches Agronomi ques de Gem bloux. 23 (2): 123-152.

Mohapatra, L.N. Sontakke, B.K. and Rana singh, N. 2010. Enhancement of crop production through bee pollination. Orissa review, September, 2010. pp 4447.

Panda, P. Nanda,U.K., Mohapatra, H. and Padhi, J. 1989. Insect pollination in some oil seed crops in Orissa. Indian Bee Journal. 51: 97-98.
Prasad, D. Hameed, S.F., Singh, R., Yazdani, S.S. and Singh, B. 1989. Effect of bee pollination on the quantity and quality of rai crop (Brassica juncea Coss.). Indian Bee Journal. 51 (2): 45-47.

Sanas, A.P., Narangalkar, A.L., Godase, S.K. and Dalvi, V.V. 2014. Effect of honeybee pollination on quantitative yield parameters of mustard (B. juncea) under Konkan condition of Maharastra. Green Farming. 5 (2): 241-243.

Singh, R., Chaudhary, B.K., Bhowmick and Singh, R.P. 2005. Honeybee flora of Bihar, Uttar Pradesh and Madhy Pradesh. International Beekeeping Congress, Nov. $13^{\text {th }}-18^{\text {th }} 2005$, Bangalore, India. pp.53.

Thapa, R.B. 2006. Honeybees and other insect pollinators of cultivated plants: A review. J. Inst.Agric. Anim.Sci. 27: 123.

Verma, S.K. and Joshi, N.K. 1983. Studies on honeybees in the pollination of cauliflower (Brassica olercea L. var. Botryitis). Indian Bee Journal. 45 (3): 45-55.

\section{How to cite this article:}

Patidar, B.K., K.N. Ojha and Khan, I.U. 2017. Role of Honeybee (Apis mellifera) in Enhancing Yield of Mustard in Humid Region of Rajasthan, India. Int.J.Curr.Microbiol.App.Sci. 6(7): 1879-1882. doi: https://doi.org/10.20546/ijcmas.2017.607.224 